\title{
Consumer Responses to CSR Driven Microfinance Strategy of Banks-An Empirical Investigation Based on India
}

\author{
Saju Jose ${ }^{1}$, Robert Rugimbana ${ }^{2} \&$ Terry Gatfield ${ }^{3}$ \\ ${ }^{1}$ Department of Marketing, College of Business Administration, Abu Dhabi University, UAE \\ ${ }^{2}$ Faculty of Management Sciences, Tshwane University of Technology, Pretoria, South Africa \\ ${ }^{3}$ Department of Marketing, Griffith University, Brisbane, Australia \\ Correspondence: Saju Jose, Department of Marketing, College of Business Administration, Abu Dhabi \\ University, UAE. E-mail: sajuvjose@hotmail.com, saju.jose@adu.ac.ae
}

Received: April 8, 2012 Accepted: August 7, 2012 Online Published: October 16, 2012

doi:10.5539/ijbm.v7n21p1 URL: http://dx.doi.org/10.5539/ijbm.v7n21p1

\begin{abstract}
Purpose-There exists only limited research investigating microfinance customers' reactions on CSR initiatives of financial institutions. The purpose of this study is to investigate the extent to which the consumers of selected microfinance institution and some new age banks in India perceive the financial services provided in the context of well known corporate social responsibility (CSR) principles. It investigates whether consumers of microfinance under the CSR banner have repurchase intentions and if so why they do that?

Design/methodology/approach-A representative sample of 301 banking customers from ICICI and ABN Amro Bank located in the state of Tamilnadu and Kerala was recruited through a microfinance institution funded by the abovementioned banks. The approach of the study was to determine consumer experience and contentment with regard to the CSR strategy of the banks. A cluster sampling approach was followed, with each State representing a cluster. The main instrument to survey customers was the Consumer Discontentment Scale (CDS), developed by Lundstrom and Lamont (1976). The questionnaire was designed to collect the contentment and discontentment of customers.
\end{abstract}

Findings-Consumers were content with the level of CSR activity. However the research found only a weak link between contentment and purchase intention. The study seems to suggest that it is not the CSR fit of microfinance and banks which is bringing rewards in the form of consumer re purchase.

Originality/value-This is the first research examining microfinance customers' contentment in response to different CSR initiatives of New Age Banks in India and the potential link between CSR contentment and purchase intention. It has implications for banks developing microfinance strategies under the CSR banner.

Keywords: corporate social responsibility, contentment, discontentment, microfinance, purchase intention

\section{Introduction}

Millions of dollars are set aside for corporate social responsibility (CSR) programmes by retail banks to strengthen both their reputations and their relationships with stakeholders, in particular, the customers (McDonald and Rundle-Thiele, 2008).A great deal of research has been undertaken in recent years in the area of retail banks commitment to CSR principles and its implications (Snider et al 2003, Maitland 2002; Pattern 2002 and Paul 2002; Kok et al 2001). In the wake of increased competition among retail banks, researchers have now focussed a lot of their attention towards finding out whether retail banks are undertaking sustainable business practices (Sweeny et al., 2001). Importance of Microfinance surfaces in this context. Microfinance is seen as an important means to increase productivity of the poor (Joseph, 1993). The increased popularity of microfinance among different financial institutions is due to the underlying belief that involvement in microfinance programmes would help them to retain credibility as development agencies (Remenyi and Quinones, 2000). This is particularly important for banks entering into the microfinance arena under the CSR banner. Banks and Microfinance finance Institutions (MFI) are implementing CSR by using financial initiatives such as microcredit and microfinance schemes, ethical, social and environmental funds, low-income banking, and removal of barriers to credit access (Prior and Argandona, 2008). There is a strong belief that CSR initiatives have the powerful potential to make positive contributions to addressing the needs of disadvantaged communities in developing countries. The business 
rewards of CSR tend to be greater when the social initiative is related to a company's core competency (CSR fit) and deals with issues that consumers care about (Kotler and Lee, 2005, Menon and Kahn, 2003, Sen and Bhattacharya, 2001). Social and business interests are not necessarily contradictory but can indeed reinforce each other (Kotler and Lee, 2005, Porter and Kramer, 2002, Prahalad, 2005). Based on the literature, the strategy of banks offering microfinance under the banner of CSR, one could argue that there is a perfect CSR fit .This strategy could lead to business rewards like increased reputation, consumer repurchase, and favourable evaluation from stake holders. However there is a dearth in the marketing literature especially in bank marketing exploring efficacy of the aforementioned strategy, which in theory claims to have a perfect CSR fit (Banks offering microfinance under CSR banner).

Banks like Hongkong and Shanghai Banking Corporation (HSBC), Angemene Bank Netherland (ABN Amro) have large clientele in microfinance spreading across different countries, including India. The microfinance market in India is becoming increasingly competitive with local banks, like the Industrial Credit and Investment Corporation (ICICI) Bank, also joining the fray. This raises a few fundamental questions: How effective is this strategy of retail banks (offering microfinance under the CSR Banner) in achieving sustainable development? How do managers and customers perceive these strategies? These claims are being examined in the light of relevant theory and primary data. The paper begins with a review of the research stream, CSR as a stakeholder obligation and then relevant studies connecting CSR, customers, banks are examined followed by data analysis, finally based on the results the paper ends with a discussion on the rationale behind the aforementioned strategy of the financial institutions.

\section{Literature Review}

\subsection{CSR as A Stakeholder Obligation}

The research stream of stakeholder obligation emphasises creating value for multiple stakeholders, as opposed to stockholders alone (Agle et al., 1999; Caroll, 1999; Davenport, 2000). Stakeholder is defined by Freeman (1984) as any individual or group who can affect, or be affected by, organisation objectives. Stakeholders can be customers, employees, suppliers, community groups and managers (McWilliams and Siegel, 2001). The proponents of this research stream emphasise that the purpose of the organisation is to serve the larger societal stakeholders, not just shareholders (Freeman, 1984, Waddock, Badwell \& Graves, 2002). They argue that stakeholders are becoming more organised and have been pushing for greater social responsibility from organisations. Stakeholders such as customers, vendors and employees seek to influence organisations (Freeman, 1984). These stakeholder groups look for ethical business behaviours, stakeholder commitment and environmental commitment as indicators of social responsibility. Customers have always been an important stakeholder group which attracted the attention of organisations.

\subsection{CSR and Customers}

Finding a way of incorporating responsiveness to stakeholder needs is vital for a company's management. This is because companies cannot operate optimally without the support of its important stakeholders (Clarkson, 1995). One important driver of CSR is demand from customers. The following sections will evaluate the important and the recent studies conducted in CSR literature that deals with customers. Importance will be given to studies examining consumer reaction towards CSR activities pursued by a firm which is the focus of this study.

One of the primary motivations for organisations to engage in CSR activities is, arguably, to attract consumers and shareholders. Many organisations now use CSR to differentiate their organisations from competitors (Fombrun and Shanley, 1990; Sen and Bhattacharya, 2001; Turban and Greening, 1997). Albinger and Freeman (2000) suggest that when firms engage in CSR activities they are improving their reputations, which in turn may provide competitive advantage. This view reinforces Greening and Turban's (2000) research conclusion that companies demonstrating higher levels of CSR are perceived as having better reputations. For example, some firms have marketed their reputation for producing organically grown fruit and pesticide free vegetables to attract consumers who have expressed concerns about genetically altered and chemically affected food (McWilliams and Siegel, 2001). The reputation of socially responsible firms attracts new customers, and it also gives consumers a feeling that they are being responsible by supporting the organisation with a high CSR. McWilliams and Siegel (2001) suggest that companies should use social responsibility as a means of differentiating among providers and creating demand for products. Yet there is no widespread evidence that consumers respond to CSR in general (Davenport, 2000, Harrison and Freeman, 1999). However, some studies support the view that consumers respond to CSR in a positive way if they identify an organisation as having similar perspectives as their own (Maignan and Ferrell, 2001; Webb and Mohr, 1998). 
Sen and Bhattacharya (2001), in their research, focused on the key mediating and moderating factors on consumer responses to CSR activities. The authors suggested that the company's CSR activities led to more favourable company evaluations and greater purchase intentions through building consumer-company congruence. Congruence aligns a company's interests with the customer's interest, which results in favourable consumer attitudes. The consumer will have a more favourable evaluation and high purchase intention if the company's traits, expressed through CSR activities, overlap with the consumer's values. The authors argue that a company's CSR actions would produce a more positive effect in consumer company evaluation and purchase intention if the company selected a cause highly supported by its target consumers. However, studies have also revealed that CSR initiatives do not always generate positive effects. They can hurt a company when consumers are sceptical of the company motives underlying its CSR activities (Fairclough, 2002; Landman et al., 2002).

According to the Cone Corporate Citizenship Study (2004) consumers punish bad corporate citizens in various ways. If a consumer finds out about a company's negative practices, 90 percent of those surveyed said that they would consider switching to another company's product or service. The study also identified that consumers are willing to reward companies that meet or exceed their expectations in fulfilling the societal obligation. 86 percent of respondents surveyed said that if the price and quality were similar they would switch to a brand that was associated with a cause.

The earlier research on CSR primarily focused on the short-term, transactional business outcomes such as company product evaluation and purchase behaviour. More recent research on CSR has examined the long-term relational outcomes, such as consumer loyalty, resilience to negative information and consumer advocacy behaviour (Du et al., 2007; Klein and Dewar, 2004; Lichtenstein et al., 2004; Peloza, 2006). Liechtenstein et al; (2004) found that consumers are more emotionally attached and more loyal towards companies that engaged in CSR activities. Klein and Dewar (2004) explored the benefits due to positive CSR associations. In a 'product harm' crisis (a situation that creates consumer uncertainty about product quality), positive CSR associations can minimise the damage done to a company. This is because consumers are more likely to attribute the crisis to the sources external to the company instead of blaming the company for the crisis. Klein and Dewar's findings suggest that positive CSR associations are like an insurance policy that can be instrumental in reducing the risk of damage to a company's brand evaluations in the event of calamity. Du et al; (2007) examined the business benefits associated with a CSR-based positioning strategy. The authors compared the business benefits of CSR initiatives undertaken by various brands in the same product category. The study found that CSR initiatives of these brands delivered both short-term transactional outcomes, such as greater purchase likelihood, and long-term relational outcomes, such as greater customer loyalty and advocacy behaviours.

In the market place, more and more companies are taking a strategic approach towards CSR. They seek to strengthen their relationship with consumers and to reap relationship rewards through CSR initiatives. More companies are selecting social issues that relate to their core product and core market. They are also supporting issues that provide opportunities to gain access to some strategic market segments (Kotler and Lee, 2005). In the era of decreased customer trust and corporate scandals, firms are increasingly resorting to social initiatives to gain competitive advantage (Porter and Kramer, 2006). This in turn helps them derive strategic marketing benefits (Kotler and Lee, 2005). Overall, researchers have found that the business benefits from CSR range from short-term benefits in the form of favourable product evaluations, purchase and long-term benefits such as stronger consumer company relationship in the form of greater consumer loyalty and advocacy behaviours. As disused earlier the business rewards of CSR tend to be greater when the social initiative is related to a company's core competency (CSR fit) and deals with issues that consumers care about (Kotler and Lee, 2005; Menon and Kahn, 2003; Sen and Bhattacharya, 2001). The following section will discuss studies that have been conducted on CSR activities pursued by companies in the financial sector.

\subsection{Banks and CSR}

Many studies have been conducted into the reasons why customers choose a particular bank (Erol et al., 1990; Gerrard and Cunningham, 1997; Naser et al., 1999; Sudin et al., 1994). These studies have identified a number of such factors: friends' recommendation, convenience (i.e. the location), reputation of the banks, and availability of credit, competitive interest rates, friendliness of banks staff, low service charges, adequate banking hours, availability of ATMs, special services and the quality of services on checking accounts. The key stakeholders for the banks have been specifically identified as owners, borrowers, depositors, regulators and managers (Yamak and Suer, 2005). In the context for this study, discussion will focus on customers. According to Reinfer (1997), the needs of the consumer in the banking industry are security, access, liquidity, interest and social responsibility. Hodgson (2002) and Orgizek (2002) argue that banks have an inherent social responsibility to know the customer. Understanding the customer's requirements imposes a broad responsibility on having to know the financial affairs 
of the customers. This guards customers from being sold inappropriate policies or investments. The banking industry provides society with tools for managing savings and investing money. They also provide funds for productive uses in the form of investment projects and, thereby, play a role in sustainable economic and social development.

One challenge the entire retail banking industry is currently facing is overcoming the negative perception of the industry's concern for consumer welfare (Decker, 2004). Orgizek (2002) argues that banks that integrate CSR policies by investing in socially responsible investments and improving CSR awareness achieve market benefits and competitive advantage. He further suggests that to realise any advantage from CSR a bank has to translate the CSR agenda into its core business activity. Numerous bank managers have responded to the necessity for complying with social responsibility requirements (Ogrizek, 2002). Researchers have debated the advantages and disadvantages of social responsibility in banking and other marketing efforts. The primary debate centres on the cost of investing in CSR activities and the benefits for the bank (Bloom et al., 1995). Asher (1991) studied the effect of green marketing on consumer behaviour at ATMs. He examined the advertising campaigns around environmentally friendly contributions, which resulted in the increase of ATM withdrawals. It was found that ATM withdrawals went up by $56 \%$ in 1988-1990(Asher, 1991). Fenn (1995) examined the result of corporate policy of banks in hiring disabled employees. The result revealed an increase in productivity and a decrease in staff turnover. Bosone (2001) emphasises the public relations benefits of the bank as a result of engaging in socially responsible marketing. Green marketing and charitable causes have also been shown to be important in bank marketing (Bosone, 2001).

Pomering and Dolnicar (2006) conducted a quantitative study surveying four hundred customers of different banks in Australia to assess the comparative sensitivity of customers to different CSR activities in the banking industry. The findings demonstrated that a considerable proportion of customers look favourably upon CSR initiatives once made aware of them (Pomering and Dolnicar, 2006). Rugimbana et al; (2005) reported in their study that customers of retail banks in New South Wales, Australia, were discontent with their banks, particularly their product strategies, followed by their communications. In Malaysia, Dusuki and Dar (2005) conducted a quantitative study with 1500 respondents from the Islamic banking industry to examine their perceptions toward CSR of various stakeholders, which comprised of managers, employees, regulators, Islamic legal advisers, customers, depositors and local communities. The results revealed that stakeholders did not consider that being socially responsible was costly and not good for the sustainability of the bank. Various stakeholders agreed that Islamic banks should show a higher level of social responsibility compared to conventional banks, and that they should have greater commitment to social responsibility.

The new age banks in India, namely ICICI bank and ABN Amro, selected for this study have clearly stated that they are pursuing microfinance as part of their CSR. Despite the commercial nature of the banks and the heavy competition in India's financial sector, the above statement clearly indicates that these banks are trying to make a difference by positioning themself as responsible corporate citizens through their microfinance initiatives in the form of CSR. The banks have ventured into the microfinance sector to achieve these goals by partnering with Microfinance institutions which act as inter mediatory between bank and the customers. This is very similar to the strategic approach towards CSR suggested by (Kotler and Lee, 2005; Menon and Kahn, 2003; Sen and Bhattacharya, 2001; ,Ogrizek, 2002). The banks are trying to fulfil the social need of providing financial aid to the poor through microfinance. By targeting the rural poor of India, these banks have developed a key strategic market segment. By following this strategy, new age banks are trying to achieve the dual advantage of being good corporate citizens while also embarking on profitable ventures. Those who support the adoption of CSR policies strongly feel that such practices may enhance the reputation of the bank and, subsequently, enable companies to reap long term strategic benefits by maintaining its legitimacy, competitiveness and sustainability in the market (Burke and Logsdon 1996, Lantos 2001, Porter and Kramer, 2002, Johnson 2003). CSR is seen as a medium for sending and receiving relevant information to the target audience, which has an impact on an organisation's legitimacy. Research conducted on financial institutions points out to the benefits of being socially responsible. Noted studies include Orgizek (2002), Asher (1991), Pomering and Dolnicar (2006). The result of all these studies suggests that consumers are generally satisfied with the CSR commitment of the banks and this could result in repurchase intention by the consumers. In the case of some new age banks in India, microfinance is included as part of CSR and the microfinance interventions are expected by banks to carry messages regarding organisational legitimacy to the target audience. For example, ICICI Bank is the pioneer in establishing microfinance in India among the new age banks, and to date has the largest number of consumers in microfinance. It would be quite interesting to know the contentment of consumers about the CSR commitment of the banks and whether it would affect the repurchase decision of the customers. Hence, the research proposed 
the following hypotheses.

\section{H 1 a-Customers of microfinance are content with the CSR commitment of the MFI}

\section{CSR Commitment and Purchase Intention}

The evidence from literature on CSR suggests that consumer responses to CSR could be different. Studies by some researchers found that consumers respond to CSR in a positive way if they identify an organisation as having similar perspectives as their own (Maignan and Ferrell, 2001; Webb and Mohr, 1998). Sen and Bhattacharya (2001), in their research, focused on the key mediating and moderating factors on consumer responses to CSR activities. The authors suggested that the company's CSR activities led to more favourable company evaluations and greater purchase intentions through building consumer-company congruence. Congruence aligns a company's interests with the customer's interest, which results in favourable consumer attitudes. The consumer will have a more favourable evaluation and high purchase intention if the company's trait expressed through CSR activities overlap with the consumer's values. The results of the survey will also find out if there is any link between consumer (dis)contentment of CSR activities and purchase intention. In other words, would the consumer who is happy with the CSR activities of the MFI show more loyalty towards MFI. This phenomenon was tested by the following hypothesis.

\section{H 1 b-The degree of Contentment on CSR commitment is positively related to purchase intention}

\section{Research Methodology}

A representative sample of banking customers from ICICI and ABN Amro Bank located in the state of Tamilnadu and Kerala was selected through a microfinance institution funded by the abovementioned banks. The State of Tamilnadu and Kerala are located in the Southern part of India having large numbers of rural customers of microfinance. The approach of the study was to determine consumer experience and contentment with regard to the CSR strategy of the banks. A cluster sampling approach was followed, with each State representing a cluster. The cluster sampling approach can be based on any natural occurring grouping (Saunders, et al, 2008).

The main instrument to survey customers was the Consumer Discontentment Scale (CDS), developed by Lundstrom and Lamont (1976). The questionnaire was designed to collect the contentment and discontentment of customers. In this context, consumer discontent was defined as the collection of attitudes held by consumers toward the strategies deployed by new age banks, mainly in areas related to CSR. Statements were modified from the original pool of items developed by Lundstrom and Lamont (1976) to measure the (dis)contentment of customers of microfinance. The questionnaire consisted of 17 statements measuring consumer (dis)contentment on CSR. The widely used Likert scale was used for this instrument. A Likert scale requires the respondent to indicate the degree of agreement and disagreement with a variety of statements.

The original Consumer Discontent Scale (CDS) was an eighty-two item self-report measure. However, they were pruned to17 items for this study. Moreover some of them were found to be redundant as they did not match the objectives of the study. The 17 items can be considered to be a subset of the 82 original items. In the original model, each item is scored on a six-point Likert scale from "strongly agree" to "strongly disagree" (Lundstrom \& Lamont, 1976; Rugimbana et al., 2005). While the scale contains both positive and negative statements, most of the items have a negative orientation (Lundstrom \& Lamont, 1976). Positive statements are scored from 1 to 6 for "strongly agree" to "strongly disagree", and negative statements are reversed, scoring from 6 to 1 ranging from "strongly disagree" to "strongly agree" (Lundstrom \& Lamont, 1976). The 17 statements for this study used a scoring of 1-5 to ease responses and data entry for analysis. A five point scale is quite simple for the researcher to read out and analyse the complete list of scale descriptors. This clarification is lengthier for the higher point format (Dawes, 2008). Each set of statements measured one aspect of the consumer (dis)contentment towards the CSR strategies examined for the study.

\section{Data Collection and Analysis}

The customers of microfinance organised themselves into Self Help Groups (SHGs) and they held meetings every week. Each SHG consisted of 15 to 20 members. The data was collected by visiting 10 SHGs each in Kanyakumari and Trichur district of Tamilnadu and Kerala respectively. The questionnaire was distributed at the end of the meeting. After each SHG meeting the researcher gave a brief introduction, explaining the purpose of the study assuring the respondents of strict anonymity. Out of the total of 316 questionnaires collected, eight of them were found to be incomplete. The response rate was 97.5 percent. This is in line with the claims of Saunders et al (2006) that delivery and collection questionnaires by following this method can receive up to 98 percent response rate. After checking for outliners the final set of data comprised 151 Malayalam questionnaires (Language of Kerala) and 150 Tamil (Language of Tamilnadu) questionnaires, which make a total data set to 
301.The final 301 questionnaires, were all used for analysis of the research.

\subsection{Contentment and Discontentment Analysis of Variables-Reliability Test}

Consumer sentiments cannot be measured by one or two questions. The relevant information is extracted through a number of questions. Questions are like jigsaw puzzles which when taken together give the answer without prejudice. Therefore the questions asked must have some amount of correlation. Reliability tests measure the extent of correlation among the questions asked. If the questions are irrelevant the correlation will be poor. The researcher has selected internal consistency and the split-half reliability tests for the questionnaires framed for quantitative analysis. The internal consistency was estimated by Cronbach's alpha $(\alpha)$. The analysis was done using SPSS. A combined analysis of both the respondents from State of Kerala and Tamilnadu was undertaken to gauge the (dis)contentment on various issues. The reliability tests conducted produced the following results.

\subsection{CSR}

A total of 17 questions were used to measure the contentment/discontentment of consumers on the CSR angle of microfinance. The reliability test produced the following results.

Table 1. Reliability test results of CSR

\begin{tabular}{lc}
\hline No. of Items & 17 \\
Alpha & 0.7631 \\
Reliability Coefficients & \\
Correlation between forms $=.7008$ & Equal-length Spearman-Brown $=.8241$ \\
Guttmann Split-half $=.8235$ & Unequal-length Spearman-Brown $=.8245$ \\
Items in part 1 & Items in part 2 \\
Alpha for part $1=.5394$ & Alpha for part $2=.6383$ \\
\hline
\end{tabular}

Table 2. Analysis of CSR statements-percentage breakdown

\begin{tabular}{|c|c|c|c|c|c|}
\hline No & Statement & Q.NO & Agreed & Disagreed & Neutral \\
\hline 1 & Primary motive of the bank is to increase profits. & 2.2 & $43 \%$ & $43 \%$ & $14 \%$ \\
\hline 2 & $\begin{array}{l}\text { Microfinance providers are helping the community by } \\
\text { providing them with work. }\end{array}$ & 2.21 & $57 \%$ & $37 \%$ & $6 \%$ \\
\hline 3 & $\begin{array}{l}\text { Many Microfinance providers listen to customer complaints } \\
\text { but then do nothing. }\end{array}$ & 2.19 & $18 \%$ & $72 \%$ & $10 \%$ \\
\hline 4 & $\begin{array}{l}\text { Often Microfinance providers cannot be trusted in what } \\
\text { they say. }\end{array}$ & 2.14 & $23 \%$ & $59 \%$ & $18 \%$ \\
\hline 5 & $\begin{array}{l}\text { Microfinance is another example of banks trying to make } \\
\text { profits at the expense of the poor community. }\end{array}$ & 2.8 & $8 \%$ & $81 \%$ & $11 \%$ \\
\hline 6 & $\begin{array}{l}\text { As soon as the Microfinance Provider gets your business, } \\
\text { they forget you. }\end{array}$ & 2.31 & $26 \%$ & $74 \%$ & 0 \\
\hline 7 & $\begin{array}{l}\text { Micro Finance Provider advertises special deals to get the } \\
\text { customer in, in order to sell them something else. }\end{array}$ & 2.20 & $18 \%$ & $82 \%$ & 0 \\
\hline 8 & $\begin{array}{l}\text { Often the purchase decision of micro loans offered by banks } \\
\text { is due to peer pressure. }\end{array}$ & 2.17 & $20 \%$ & $72 \%$ & $8 \%$ \\
\hline 9 & $\begin{array}{l}\text { Microfinance providers take advantage of the disadvantaged } \\
\text { by charging higher prices. }\end{array}$ & 2.39 & $15 \%$ & $72 \%$ & $13 \%$ \\
\hline 10 & $\begin{array}{l}\text { The main reason any Microfinance provider contributes to a } \\
\text { community is for a financial return. }\end{array}$ & 2.37 & $26 \%$ & $52 \%$ & $22 \%$ \\
\hline 11 & $\begin{array}{l}\text { Microfinance provider's profits are high, yet they keep } \\
\text { raising fees. }\end{array}$ & 2.35 & $55 \%$ & $26 \%$ & $19 \%$ \\
\hline
\end{tabular}




\begin{tabular}{|c|c|c|c|c|c|}
\hline 12 & $\begin{array}{l}\text { Advertising (example, insurance policies) tempts people to } \\
\text { purchase microfinance products without considering the } \\
\text { consequences. }\end{array}$ & 2.34 & $75 \%$ & $25 \%$ & 0 \\
\hline 13 & $\begin{array}{l}\text { Members of staff of Micro Finance Providers nowadays are } \\
\text { less concerned with the needs of the customers. }\end{array}$ & 2.29 & $39 \%$ & $61 \%$ & 0 \\
\hline 14 & $\begin{array}{l}\text { The consumer of microfinance has lesser importance to a } \\
\text { Micro Finance Provider when compared to a shareholder. }\end{array}$ & 2.28 & $46 \%$ & $46 \%$ & $8 \%$ \\
\hline 15 & $\begin{array}{l}\text { Micro Finance Providers do not want to help local industry } \\
\text { because it is not profitable. }\end{array}$ & 2.27 & $26 \%$ & $74 \%$ & 0 \\
\hline 16 & $\begin{array}{l}\text { Micro Finance Providers encourage the consumer to borrow } \\
\text { more than they need. }\end{array}$ & 2.25 & $22 \%$ & $78 \%$ & 0 \\
\hline 17 & $\begin{array}{l}\text { What Micro Finance Providers really care for is to make the } \\
\text { most money they can. }\end{array}$ & 2.22 & $39 \%$ & $49 \%$ & $12 \%$ \\
\hline
\end{tabular}

There were two types of questions asked under the CSR banner. First type are questions whose answers in the affirmative increased the credibility of banks in the context of CSR. These are positive questions. A low score shows agreement. In this case a mean score of less than 3 is considered as contentment. The second type of question was whose answers were in the affirmative, which reduced the credibility of the banks in the context of CSR. They are negative questions. When respondents produce answers negating negative questions the result is positive. A high score shows agreement. On individually analysing each statement it is quite clear from Table that the consumers of microfinance are satisfied with the way banks handle microfinance activities and their commitment towards CSR.

Table 3. CSR-Analysis of statements- mean and standard deviation of CSR

\begin{tabular}{lllllll}
\hline No & Statement & Q.NO & Mean & S.D & +/-ve & C/DC
\end{tabular}

1 Primary motive of the Microfinance provider is to increase profits.

2 Microfinance providers are helping the community by providing them with work.

3 Many Microfinance providers listen to customer complaints but then do nothing.

4 Often Microfinance provider cannot be trusted in what they say.

5 Microfinance is another example of banks trying to make profits at the expense of the poor community.

6 As soon as the Microfinance provider gets your business, they forget you.

7 Micro Finance Provider advertises special deals to get the customer in, in order to sell them something else.

8 Often the purchase decision of micro loans offered by banks is due to peer pressure.

9 Microfinance providers take advantage of the disadvantaged by charging higher prices.

\begin{tabular}{|c|c|c|c|c|}
\hline 2.2 & 2.8 & 1.3 & - & $\mathrm{X}$ \\
\hline 2.21 & 2.4 & 1.4 & + & $\checkmark$ \\
\hline 2.19 & 3.6 & 1.1 & - & ' \\
\hline 2.14 & 3.5 & 1.1 & - & $\checkmark$ \\
\hline 2.8 & 3.8 & 0.9 & - & $\checkmark$ \\
\hline 2.31 & 3.3 & 1.3 & - & $\checkmark$ \\
\hline 2.20 & 3.9 & 0.8 & - & $\checkmark$ \\
\hline 2.17 & 3.6 & 1.2 & - & $\checkmark$ \\
\hline 2.39 & 3.6 & 0.9 & - & $\checkmark$ \\
\hline
\end{tabular}


10 The main reason any bank contributes to a community is for a 2.37

3.1 financial return.

11 Microfinance providers' profits are high, yet they keep raising fees.

12 Advertising (example, insurance policies) tempts people to purchase microfinance products without considering the consequences.

13 Members of staff of Micro Finance Providers nowadays are less concerned with the needs of the customers.

14 The consumer of microfinance has lesser importance to a Micro Finance Provider when compared to a shareholder.

15 Micro Finance Providers do not want to help local industry because it is not profitable.

16 Micro Finance Providers encourage the consumer to borrow more than they need.

17 What Micro Finance Providers really care for is to make the most money they can.
2.35

2.4

1.2

- X

2.34

3.6

0.8

2.29

3.5

1.1

2.28

2.8

1.4

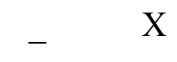

2.27

3.5

1.1

2.25

3.7

1.1

2.9

1.4

2.22

Positive Statement

$=+\mathrm{ve}$

Negative Statement $=-$ ve

Out of 17 questions, 16 of them were negative questions. Issues that prompted responses of strong discontentment were very few. The consumers expressed strong contentment on some important issues like statement 2.8, "Microfinance is another example of banks trying to make profits at the expense of the poor community". The mean of the aforementioned statement is 3.86 and the standard deviation is 0.940 . Eighty one percent of the recipients disagreed with this statement and only 8 percent agreed with it. Ten percent took a neutral attitude. It is clear that most of the respondents do not feel that they are being exploited by the banks. This is an expression of contentment on the part of recipients.

MFI's are often accused of pushing people into virtual spirals of poverty by providing them with more loans. However, when responding to question number $2.25,78 \%$ of consumers disagreed with the statement that the MFI encouraged them to borrow more. Another criticism of MFI's is that some of them express traits of a pure money lending organisation. It seems that the majority of the consumers of this survey did not agree with this. Responding to the statement "As soon as the Microfinance provider gets your business, they forget you”, 74 percent of the respondents disagreed with the statement, only 26 percent of recipients agreed with the statement. This shows that the majority of the recipients were content with the way the banks were running the business. However, one important element that has to be noted here is that the recipients of microfinance do not deal directly with the banks. Only the members of the field staff of the MFI are directly involved with the recipients. Therefore this contentment should be indirectly attributed to the banks. On issues like helping the local industry, catering towards the needs of society, consumers expressed strong contentment. One interesting point to note is the opinion of the consumers, on statement 2.2, "Primary motive of the Microfinance provider is to increase profits". This statement produced a mean of 2.85 and the standard deviation is 1.371 . A standard deviation of 1.371 for a mean of 2.85 is high. Forty three percent of the respondents agreed to the statement and 43 percent disagreed. 14 percent gave a neutral answer. The results clearly show the wide disparity in thinking on this issue.

Out of the 17 statements, consumers expressed discontentment on only two statements, questions 2.35 and 2.28. Responding to the negative statement 2.28, consumers felt that they were less important to the bank when compared to the shareholders. The mean for the statement is 2.87 and the standard deviation is 1.482 . A standard deviation of 1.482 for a mean of 2.87 is indicative of the diverging opinions in this item. It is interesting to note that 46 percent of respondents felt that the statement was true. At the same time, 46 percent felt the opposite. This shows 
that banks have not taken the recipients of microfinance into their confidence and made them feel important. Had there been contentment, there would have been more recipients disagreeing with the item. In fact, recipients felt less important. This shows their discontentment. This supports Johnson's (1971) view of CSR; Johnson's main argument was that a socially responsible firm should look after the interests of stockholders.

\subsection{Overall Mean for CSR}

The overall mean for the 17 statements was computed using SPSS. All negative questions were reverse coded and the common mean for CSR and standard deviation was determined using SPSS taking all 17 questions into account. The result is given in Table below. The overall mean is $2.59(<3)$ indicating that consumers of microfinance were relatively content with CSR commitment of the MFI.

Ho: Customers of microfinance are discontent with the CSR commitment of the MFI ( $\mu \geq 3)$ and the discontentment will not result in future purchase intention.

HA: Customers are content with the CSR commitment of the MFI $(\mu<3)$ and the contentment will result in future purchase intention.

The hypothesis $H 1$ a (Customers of microfinance are content with the CSR commitment of the MFI) and H $1 \mathrm{~b}$ (The degree of Contentment on CSR commitment is positively related to purchase intention) are individually tested in this section which is divided into two parts. The first part tests the contentment and discontentment on CSR commitment. The second part tests the relationship between contentment and purchase intention.

On the overall analysis of the 17 statements related to CSR, it is quite clear that consumers of microfinance are generally satisfied with the strategies related to CSR. There are some disagreements on certain aspects. Those consumers tested generally disagreed with negatively worded statements, showing clearly that they have firm opinions on this matter. Therefore it is to be presumed that consumers of microfinance are content with regard to the services offered by the banks and SHGs.

Sixteen questions related to CSR were negative. The overall CSR score was computed as the mean of 17 CSR items after reversing the 16 questions using SPSS. The overall mean of CSR is found to be 2.6 and the standard deviation is 0.50 . The corresponding standardised test statistic to be tested Ho: $\mu \geq 3$ against HA: $\mu<3$ is $=-11.31$. The corresponding $\mathrm{p}$ value is 0.024 , which is less than the level of significance $\alpha=0.05$. Therefore the null hypothesis Ho: $\mu \geq 3$ (customers of microfinance are discontent with the CSR commitment of the MFI) should be rejected. This means there is enough evidence to support the alternate hypothesis, HA: $\mu<3$ that the "customers of microfinance are content with the CSR commitment of the MFI". Correlation between CSR and repurchase intentions is calculated using SPSS. The results are given in Table below:

Table 4. Correlations between CSR and purchase intention

\begin{tabular}{llll}
\hline & & CSR & Purchase Intention \\
\hline CSR & Pearson Correlation & 1 & $.273(* *)$ \\
& Sig. (2-tailed) &. & .000 \\
Purchase Intention & Pearson Correlation & $.273\left(^{* *}\right)$ & 1 \\
& Sig. (2-tailed) & .000 &. \\
\hline
\end{tabular}

** Correlation is significant at the 0.01 level (2-tailed)

It can be seen that correlation between purchase intention and CSR is 0.273 indicating the correlation is very weak. As can be seen from the above table, the $p$-value to test Ho: Correlation $=0$ against the HA : Correlation $>0$ is 0.000 . Since the $p-$ value is less than level of significance $\alpha=0.05$, the null hypotheses is rejected, and conclude that the correlation is significantly different than zero and positive. This result indicates that there are many other factors that influence the repurchase intentions. The coefficient of correlation is only 0.273 , coefficient of determination is 0.075 . This value shows that $7.5 \%$ of the repurchase intentions are explained by the CSR component of the schemes. 


\section{Discussion and Conclusion}

On the issue of CSR, Consumer perceptions are varied, and there was a lot of indecision on the part of consumers in giving a clear cut verdict. CSR as a social obligation has been one of the most prominent streams in the CSR literature. Numerous researchers have explicitly put forward the view that business should look after society's welfare. For many of them, CSR meant sacrificing profits and giving out dole. Carroll (1999) defined discretionary activities as philanthropic obligation, which is about actively giving back to society. Similar views were put forward by Donaldson (1982) and Fredrick (1987) when they argued that businesses and society were interdependent and that they coexisted (Donaldson, 1982, Fredrick, 1987). The banks who selected for the study seemed to follow this CSR stream from the literature and did not insist on pursuing the CSR angle. This attitude led to a situation where new age banks and MFIs remained as money lenders to the consumers of microfinance. This duty they did well, and consumers were happy with it. However, on specific queries, consumers were not happy, namely:

1) Bank profits are high, yet they keep raising fees.

2) Primary motive of the bank is to increase profits.

3) The consumer of microfinance has lesser importance to a microfinance provider when compared to a shareholder.

4) Microfinance providers encourage the consumer to borrow more than they need.

Though, on overall analysis, (CSR mean is $2.59<3$ ) consumers were content with the level of CSR activity.

\subsection{Relation between Contentment and Purchase Intention}

On the analysis of results, the research found only a weak link between contentment and purchase intention. The correlation figure computed using SPSS was 0.27 - a value of 0.90 and above is considered to be strong (Tabachnick and Fidell, 2001). The correlation figures do not substantiate a strong relationship. This result suggest the presence of other factors which influences repurchase, responding to another question, the majority of customers said that they would use the same microfinance provider for their future needs. This irony might indicate that consumers do not have any alternative financial options. Usually the only provider of alternative finance would be local money lenders who charges exorbitant interest rates.

The literature on CSR talks in detail about the relationship between CSR and customers. The consumer responds to CSR initiatives in different ways. Evidence from the literature on consumer responses seems to be divided on this issue. Researchers like Sen and Bhattacharya (2001) argue that the consumer will show favourable company evaluation and purchase intention if they are satisfied with the CSR efforts of the company. However, studies have also revealed that CSR initiatives do not always generate positive effects (Fairclough, 2002; Landman et al., 2002). The results of this study indicate that although consumers showed purchase intention, it was not related to the CSR initiatives of the organisation. Thus the study provides empirical support to the view that CSR does not always generate positive effects. Furthermore, researchers like Kotler and Lee (2005); Menon and Kahn (2003); Sen and Bhattacharya(2001); talks about the business rewards for maintaining a CSR fit between company's core competency and CSR initiatives. However, the result of this study seems to suggest that it is not the CSR fit of microfinance and banks which is bringing rewards in the form of consumer re purchase.

\subsection{Potential Reasons on why Banks still Pursuing CSR Strategy}

Many organisations now use CSR to differentiate their organisation from competitors (Fombrun and Shanley, 1990; Sen and Bhattacharya, 2001; Turban and Greening, 1997). Albinger and Freeman (2000) suggest that when firms engage in CSR activities they are improving their reputations, which in turn may provide competitive advantage. This view reinforces Greening and Turban's (2000) research conclusion that companies demonstrating higher levels of CSR are perceived as having better reputations. Decker (2004) argues that the challenge the entire retail banking industry is currently facing is overcoming the negative perception of the industry's concern for consumer welfare (Decker, 2004).New age banks in India have a history of being warned by public authorities and consumer watch dogs about their unethical business practices. This could have affected their public image, so disclosing CSR strategies through microfinance might be an attempt to regain and enhance their public image. However to substantiate these claims further research is required into the underlying motives of Banks in pursuing microfinance under the umbrella of CSR. 


\section{References}

Ackerman, R. W., \& Bauer, R. A. (1976). Corporate social responsiveness. Reston VA: Reston.

Agle, B. R., Mitchell, R. K., \& Sonnenfeld, J. (1999). who matters to CEO's? An investigation into stakeholder's attributes and salience, corporate performance and CEO values. Academy of management journal, 42, 507-525. http://dx.doi.org/10.2307/256973

Albinger, H., \& S. Freeman. (2000). Corporate Social Performance and Attractiveness as an Employer to Different Job Seeking Populations. Journal of Business Ethics, 28(3), 243-253. http://dx.doi.org/10.1023/A:1006289817941

Asher, J. (1991). When a good cause is also a good business. Journal of bank marketing, 23, 30-32.

Barich, H., \& Kotler, P. (1991). A Framework for Marketing Image Management. Sloan Management Review, Winter.

Barone, M., Miyazaki, A. D., \& Taylor, K. (2000). The influence of cause related marketing on consumer choice: does one good turn deserve another? Journal of Academy of Marketing Science, 28, 248-62. http://dx.doi.org/10.1177/0092070300282006

Bhide, A., \& Stevenson, H. H. (1990). Why be honest if honesty does not pay. Harvard Business review, September-October, 121-129.

Black, L. D., \& Hartlel, C. E. J. (2004). Towards a typology of corporate social responsibility orientations. Journal of public affairs, 4, 125-144. http://dx.doi.org/10.1002/pa.176

Bloom, P. N., Hussein, P. Y., \& Szykman, L. R. (1995). Benefiting society and the bottom line. Journal of Marketing Management, 4, 8 .

Bosone, B. (2001). A study of banking and finance as we move into the new millennium. Journal of Banking and finance, 25, 2239-76.

Bowen, \& Howard, R. (1953). Social Responsibilities of the Businessman. Harper \& Row, New York.

Brown, T. \& Dacin, P. A. (1997). The Company and the Product- Corporate associations and consumer Product responses. Journal of Marketing, 61, 68-85. http://dx.doi.org/10.2307/1252190

Burke, L., \& Logsdon, J. M. (1996). How Corporate Social Responsibility Pays Off. Long Range Planning, 29 , 495-502. http://dx.doi.org/10.1016/0024-6301(96)00041-6

Carroll, A. B. (1979). A three-dimensional conceptual model of corporate social performance. Academy of Management Review, 4, 497-505.

Carroll, A. B. (1999). Corporate Social Responsibility-The evolution of a definitional construct. Business and Society, 38, 466-478. http://dx.doi.org/10.1177/000765039903800303

Clarkson, M. B. D. E. (1995). A stakeholder frame work for analysing and evaluating corporate social performance. Academy of Management review, 20, 92-117.

Cone Corporate Citizenship Study (2004). Retrieved from http://www.coneinc.comte accessed: 10/11/09

Davenport, K. (2000). Corporate Citizenship-A stakeholder approach for redefining corporate social performance and identifying measures for assessing it. Business and Society, 39, 210-219. http://dx.doi.org/10.1177/000765030003900205

Davis, K. (1960). Can Business Afford to Ignore Corporate Social Responsibilities?. California Management Review, 2, 70-76. http://dx.doi.org/10.2307/41166246

Dawes, J. (2008). Do Data Characteristics Change According To The Number Of Scale Points Used? An Experiment Using 5-Point, 7-Point and 10-Point Scales. International Journal Of Market Research, 50(1), 61-76.

Decker, O. S. (2004). corporate social responsibility and structural change in financial services. Managerial Auditing Journal, 19, 712. http://dx.doi.org/10.1108/02686900410543840

Donaldson, T. (1982). Corporations and Mortality, NJ, Engle wood cliffs Prentice Hall.

Drucker, P. F. (1984). The practice of management. New York, Harper and Row.

Du, S., Sen, S., \& Bhattacharya, C. B. (2007). Reaping relational rewards from corporate social responsibility: The role of competitive positioning. International journal of research in marketing, 24, 224-241. 
http://dx.doi.org/10.1016/j.jiresmar.2007.01.001

Dusuki, A. W., \& Dar, H. (2005). Does Corporate social responsibility pay off? An empirical examination of Stakeholder perspectives. Department of economics, Loughborough University, Leicestershire, UK.

Ellen, P. S., \& Deborah, J. W. (2006). Building Corporate Associations: Consumer Attributions for Corporate Socially Responsible Programs. Journal of Academy of Marketing Science, 34, 147-157.

Erol, C., Kaynak, E., \& El-Bdour, R. (1990). Conventional and Islamic banks: patronage behaviour of Jordanian

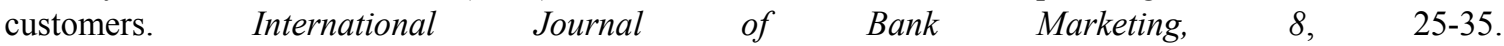
http://dx.doi.org/10.1108/02652329010004231

Fairclough, G. (2002). Study slams Philip Morris ads telling teens not to smoke-How a market researcher who dedicated years to cigarette sales came to create antismoking ads. Wall street journal, 13.

Fenn, D. (1995). The unexpected advantage. Inc. Magazine, 17, 119.

Frederick, W.C. (1960). The growing concern over business responsibility. California Management Review, 2, 54-61. http://dx.doi.org/10.2307/41165405

Fombrun, C., \& Shanley, M. (1990). What is in a name? Reputation Building and corporate strategy. Academy of Management journal, 33, 233-258. http://dx.doi.org/10.2307/256324

Fredrick, W. C. (1987). Theories of corporate social Performance in Sethi, S.P. and Falbe, C.M. Business and Society, Lexington, Lexington Books.

Freeman, R. E. (1984). Strategic management: A stakeholder approach. Boston, Pitman.

Friedman, M. (1970). Social responsibility of Business to increase its profits. Time Magazine.

Gaski, J. F. (1985). Dangerous territory- Societal marketing revisited. Business horizon, 28, 42-47.

Gerrard, P., \& Cunningham, J. B. (1997). Islamic banking: a study in Singapore. International Journal of Bank Marketing, 15, 204-216. http://dx.doi.org/10.1108/02652329710184433

Haigh, M., \& Jones, M.T. (2006). The drivers of Corporate Social Responsibility, A critical Review. The Business Review, 5, 245-51.

Harrison, J. S., \& Freeman, R. E. (1999). Stakeholders social responsibility and performance-Empirical evidence and theoretical perspectives. Academy of management journal, 42, 479-485. http://dx.doi.org/10.2307/256971

Hodgson, D. (2002). Know Your Customer: Marketing, Govern mentality and the new consumer of Financial Services. Management Decision, 40(4), 318-328. http://dx.doi.org/10.1108/00251740210426312

Jamali, D., \& Mirshak, R. (2007). Corporate Social Responsibility: Theory and practice in a Developing country context. Journal of Business Ethics, 72, 243-262. http://dx.doi.org/10.1007/s10551-006-9168-4

Johnson, H. L. (1971). Business in Contemporary Society: Framework and Issues. Belmont, Ca: Wadsworth.

Johnson, H. H. (2003). Does it Pay to be Good? Social Responsibility and Financial Performance. Business Horizons, 46, 34-40. http://dx.doi.org/10.1016/S0007-6813(03)00086-7

Jones, T.M. (1980). Corporate social responsibility revisited redefined. California Management Review, 3(22), 59-67. http://dx.doi.org/10.2307/41164877

Joseph, S. (1993). The role of state in Financial markets. World Bank annual conference on Development Economics. Washington DC.

Klein, J., \& Dewar, N. (2004). Corporate Social responsibility and Consumer attributions and brand evaluations in a product-harm crisis. International Journal of Research in Marketing, 21, 203-217. http://dx.doi.org/10.1016/j.jiresmar.2003.12.003

Kok, P., Weile, T. V. D., McKenna, R., \& Brown A. (2001). A Corporate Social Responsibility Audit within a Quality Management Framework. Journal of Business Ethics, 31(4), 285-297. http://dx.doi.org/10.1023/A:1010767001610

Kotler , P., \& Lee, N. (2005). Corporate Social Responsibility Doing The Most Good For Your Company And Your Cause. New Jersey, John Wiley \& Sons.

Landman, A., Ling, P. M., \& Glantz, S. A. (2002). Tobacco industry youth smoking prevention programs -Protecting the industry and hurting Tobacco control. American journal of public health, 92, 917-930. 
http://dx.doi.org/10.2105/AJPH.92.6.917

Lantos, G. P. (2002). The Ethicality of Altruistic Corporate Social Responsibility. Journal of Consumer Marketing, 19, 205-230. http://dx.doi.org/10.1108/07363760210426049

Lundstrom, W. J., \& Lamont, L. M. (1976). The Development of A Scale To Measure Consumer Discontent. Journal of Marketing Research, 13, 373-381. http://dx.doi.org/10.2307/3151020

Maignan, I., Ferrell, O. C., \& Hult, T. M. (1999). Corporate citizenship: Cultural antecedents and business benefits. Academy of Marketing science journal, 27, 455-469.

Manne, H. G., \& Wallich, H. C. (1972). The modern corporation and social responsibility, Washington DC, American Enterprise Institute for Public Policy Research.

Maitland, A. (2002). How to Become Good in all Areas: Corporate Social Responsibility: CSR is here to Stay-But It is Unfamiliar Territory for Most Managers. The Financial Times (London) (September 11), 15.

McDonald, L.M., \& Rundle-Thiele, S. (2008). Corporate social responsibility and bank customer satisfaction: a research agenda. The International Journal of Bank Marketing, 3(26), 170-82.

McGuire, J. W. (1963). Business and Society. New York, McGraw Hill.

Mcwilliams, A., \& Siegel, D. (2001). Corporate social responsibility: A theory of the firm perspective. Academy of Management review, 26, 117-127.

Menon, S., \& Kahn, B. (2003). Corporate Sponsorship of Philanthropic Activities-When Do They Impact Perceptions On Sponsored Brand? Journal of Consumer Psychology, 13, 316-327. http://dx.doi.org/10.1207/S15327663JCP1303_12

Naser, K., Jamal, A., \& Al-Khatib, K. (1999). Islamic banking: a study of customer satisfaction and preferences in $\begin{array}{lllll}\text { Jordan. International Journal of Bank } & \text { Marketing, 170-82. }\end{array}$ http://dx.doi.org/10.1108/02652329910269275

Ogden, S., \& Watson, R. (1999). Corporate performance and Stakeholder management-Balancing shareholder and customer interest in UK privatized water industry. Academy of Management journal, 42, 526-538. http://dx.doi.org/10.2307/256974

Ogrizek, M. (2002). The effect of Corporate Social responsibility on the branding of financial services. Journal of Financial service marketing, 6, 215-228. http://dx.doi.org/10.1057/palgrave.fsm.4770053

Paul, P. (2002). Corporate Responsibility. American Demographics, 24(5), 24.

Pomering, A., \& Dolnicar, S. (2006). Customers' Sensitivity to Different Measures of Corporate Social Responsibility in the Australian Banking Sector. ANZMAC CD. Proceedings (Australia and New Zealand Marketing Academy Conference), Brisbane, Queensland, 4-6 December 2006.

Porter, M. E., \& Kramer, R. M. (2006). Strategy and society-The link between Competitive advantage and Corporate social responsibility. Harvard Business review, 84, 78-92.

Porter, M. E., \& Kramer, M. R. (2002). The Competitive Advantage Of Corporate Philanthropy. Harvard Business Review, 80, 56-65.

Prahalad, C. K. (2005). The Fortune At The Bottom Of The Pyramid. Pennsylvania, Wharton School Of Publishing.

Prior, F., \& Argandona, A. (2008). Best practices in credit accessibility and corporate social responsibility in financial institutions. Journal of Business Ethics, 1(87), 251-65.

Remenyi, J., \& Quinones, B. (2000). Microfinance and poverty Alleviation. London.

Rugimbana, R., Strachan, G., Quazi, A., \& Keating, B. (2005). Social impact of bank closures on a small rural community: The case of Marriwa. ANZMAC 2005 Conference: Service Marketing.

Samli, A. C. (1992). Social responsibility in marketing-A proactive and profitable marketing management Quorum books.

Saunders, M., Lewis, P., \& Thornhill, A. (2006). Research methods for business students. London, Prentice Hall.

Sen, S., \& Bhattacharya, C. B. (2001). Does Doing Good Always Lead To Doing Better? Consumer Reactions To Corporate Social Responsibility. Journal of Marketing Research, 38, 225-243. http://dx.doi.org/10.1509/jmkr.38.2.225.18838 
Simmons, C., \& Becker-Olsen, K. (2006). When do social sponsorship enhance or dilute equity: Working Paper.

Snider, J., Hill, R. P., \& Martin, D. (2003). Corporate Social responsibility in the 21st century: A view from the world's most successful firms. Journal of Business Ethics, 48, 175-187. http://dx.doi.org/10.1023/B:BUSI.0000004606.29523.db

Steiner, G. A. (1971). Business and society. New York, Random House.

Sudin, H., Norafifah, A., \& Planisek, L. (1994). Bank patronage factors of Muslim and non-Muslim customers. International Journal of Bank Marketing, 12, 32. http://dx.doi.org/10.1108/02652329410049599

Sweeney ,M.E., Armstrong, A. O’Donovan, G., \& Fitzpatrick, M. (2001). Australian Banks As Corporate Citizens: Are They Toeing The Triple Bottom Line?

Tabachnick, B. G., \& Fidell L.S. (2001). Using Multivariate Statistics. New York: Harper Collins.

Turban, D. B., \& Greening, D. W. (1997). Corporate social performance and organizational attractiveness of prospective employees. Academy of management journal, 40, 658-672. http://dx.doi.org/10.2307/257057

Waddock, S., \& Graves, S. B. (2002). Responsibility: The new business imperative. Academy of Management executive, 16, 132-148. http://dx.doi.org/10.5465/AME.2002.7173581

Waddock, S. (2004). Parallel Universes: Companies, Academics and the progress of corporate citizenship. Business and Society review, 109, 5-42. http://dx.doi.org/10.1111/j.0045-3609.2004.00002.x

Walton, C. C. (1967). Corporate social responsibilities, Belmont, CA-Wadsworth.

Webb, D. J., \& Mohr, L. A. (1998). A typology of consumer responses to cause related marketing-From sceptics to socially concerned. Journal of public policy and Marketing, 17, 226-238.

Windsor, D. (2001). The future of Corporate social responsibility. International Journal of organizational analysis, 9, 225-256. http://dx.doi.org/10.1108/eb028934

Yamak, S., \& Süer, O. (2005). State as a stakeholder. Corporate Governance, 5(2), 111. http://dx.doi.org/10.1108/14720700510562695

Zenisek, T. J. (1979). Corporate social responsibility: A conceptualization based on organizational literature. Academy of Management Review, 4, 359-368. 